\title{
ASYMPTOTIC INEQUALITIES AND COMPARISON OF CLASSICAL MEANS
}

\section{Neven Elezović}

Abstract. Inequalities between linear combinations of means are the subject of interest for decades. In this paper we propose a new approach to this subject, using the concept of asymptotical expansion of means. This enables us to find necessary conditions and the optimal values for coefficients in order that the inequality between linear combination of three or four means will be valid. We restrict ourselfs to the study of the most common classical mean, leaving detailed study of parametric means to the future works.

Mathematics subject classification (2010): 26D15, 41A60.

Keywords and phrases: Asymptotic expansion; bivariate means.

\section{REFERENCES}

[1] J. ACZel, Z. PÁLES, The behaviour of means under equal increments, Amer. Math. Monthly, 95, (1988), 856-860.

[2] H. AlZER, Ungleichungen für Mittelwerte, Arch. Math. 47 (1986), 422-426.

[3] H. Alzer AND S. L. QIU, Inequalities for means in two variables, Arch. Math. (Basel), 80, 2 (2003), 201-215.

[4] P. S. Bullen, Averages still on the move, Math. Mag., 63 (1990), 250-255.

[5] P. S. Bullen, Handbook of Means and Their Inequalities,

[6] P. S. Bullen, D. S. Mitrinović, P. M. Vasić, Means and theirs inequalities, D Reidel, Dordrecht, 1988

[7] N. Elezović AND L. VUKŠIĆ, Asymptotic expansions of bivariate classical means and related inequalities, J. Math. Inequal. 8, 4 (2014), 707-724.

[8] N. ElezoviĆ AND L. VUKŠIĆ, Asymptotic expansions and comparison of bivariate parameter means, Math. Inequal. Appl. 17, 4 (2014), 1225-1244.

[9] N. ELEZOVIĆ AND L. VUKŠIĆ, Asymptotic expansions of integral means and applications to the ratio of gamma functions, Appl. Math. Comput. 235 (2014), 187-200.

[10] N. EleZOVIĆ, L. VUKŠIć, Neuman-Sandor means, asymptotic expansions and related inequalities, J. Math. Inequal. (to appear)

[11] L. Hoenn, I. Niven, Averages on the move, Math. Mag., 58 (1985), 151-156.

[12] D. S. Mitrinović, J. E. PeČArić, A. M. Fink, Classical and New Inequalities in Analysis, D Reidel, Dordrecht, 1993.

[13] E. Neuman And J. SAndor, On certain means of two arguments and their extensions, Intern. J. Math. Math. Sci., 16, (2003), 981-993.

[14] J. S ANDOR, On certain identities for means, Studia UBB, Math., 38, 4 (1993), 7-14.

[15] J. Sandor, E. Egri And R. Olah-Gal, On certain identities for means III, Adv. Stud. Contemp. Math. 19, 1 (2009), 109-122.

[16] J. SANDOR AND I. RASA, Inequalities for certain means in two arguments, Nieuw Arch. Wiskunde 15, 1-2 (1997), 51-55.

[17] J. SANDOR AND T. TRIF, Some new inequalities for means of two arguments, Intern. J. Math. Math. Sci., 25, 8 (2001), 525-532.

[18] L. VUKŠIĆ, Seiffert means, asymptotic expansions and related inequalities, Rad HAZU (to appear). 